Year:5, Volume:5, Number:10/2021
$\begin{aligned} & \text { The } \\ & \text { Sournal of } \\ & \text { Science }\end{aligned}$

DOI: $10.30520 / \mathrm{tjs}$ sosci.963128

\title{
CHINA'S ENCOUNTER WITH WEST IN THE 19TH CENTURY: POWER RELATIONS ${ }^{1}$
}

\author{
Oktay KÜÇÜKDEĞİRMENCI'²
}

\begin{abstract}
This article aims to examine power relations between China and West in the 19th century, in particular, from the first Opium War (1839-1842) to Self-strengthening Movement (1864-1884) since when Europeans, for the first time, came to China with new technologies, armaments, and ideas, and told them what is good for Chinese, Chinese were bewildered because they did not know how to respond. China had lived under its sense of superiority as mandate of heaven with its neighbours for a long centuries. They had not seen people like westerners before. They were complacent with regards to foreign world, and did not keep up with contemporary world conditions. Thus, when they encountered superior power of westerners throughout the 19th century, they failed to response successfully, and started to lose everything they believed and had for centuries. In Chinese respond to West, two strategies were put forth, which one ise a sort of external balancing, but not via military alliance with another country, but through the concept of most favoured nation clause by inviting other western countries to China in order to use "one barbarian country to another barbarian country". The other strategy China utilized is a kind of internal balancing by menas of self-strengthening movement.
\end{abstract}

Key Words: China, West, Opium War, Self-Strengthening Movement, Most-Favoured Nation Clause

\footnotetext{
${ }^{1}$ This article was derived from Oktay KÜÇÜKDEĞİRMENCİ's Master's Degree Thesis written at Atilim University, named "China and West: Power Relations During Nineteenth Century".

${ }^{2}$ Oktay KÜÇÜKDEĞİRMENCI is a Ph. D Candidate at the department of international politics in Shandong University, Qingdao, China. ORCID: 0000-0001-5914-2239, oktayd506@ gmail.com
} 


\section{Introduction}

The longest lived world power of Asia, China constrained its contact with western world for a long time, and it intentionally kept its door closed to any communication opportunities through shutting its frontiers down to western nations. Because China did not send diplomatic agents to abroad for centuries, it did not receive any single European/Western diplomats. Constitutively, even though the first contact between China and west began with Marco Polo who made an expedition to China during the Yuan Dynsty (1280-1368) in the 13th century, sides could not establish regular relations. The interplay amid China and West started in the 16th century. Thendays, the Ming Dynasty (1368-1644) was reigning over China, and under the Ming rule, China was a inward-oriented country. At that time, the only open port to European trade was in Canton city of China (Guangzhou) where Chinese and foreigners could make a contact to each other, but it was very restricted (Holcombe, 2016).

The first contact amid China and a western country happaned in the 16th century, and that country was Portugal, which sent a ship to China in 1516. Thus, Sino-Portuguese relations started to take shape via Portuguese explorer, Jorge Alvares who arrived in Guangzhou, a southern Chinese city in 1516. By 1557, Portugal set up its trading activities in southern China, and step by step expanded into Macau, and embarked on paying rent to the Ming Empire (Maddison, 2001). In this way, Portugal created a monopoly for itself in commercial activities with China. The following year, the first Portuguese ambassador came to China.

Following Portugal, some other European countries initiated to send their ships to Chinese costs. Successively, in 1575 Spain, in 1604 Netherlands, in 1637 Britain, and in 1787 the United States of America (USA) came to Chinese ports. Russia was in a more advantageous position than compared to other western states and Russia attempted to capture new territories in Siberia and became a neighbouring country via land with China (Holcombe, 2016). When a frontier issue arose amid them with the Treaty of Nerchinsk concluded in August 1689, border trade arrangements as well as border arrangements were made as well. The Treaty of Nerchinsk represents the earliest agreement signed by China and a European nation in Chinese history, and the treaty constituted for the foundation of peaceful relations between two powers more than one and a half centuries (Urbansky, 2020).

When the Qing dynasty reigned over China and announced to foreigners that Canton was the only contact and trade center for Chinese and foreigners via an imperial, all foreigners residing in Chinese cities, except for Canton, were sent away from China. China abstained from making a contact with western powers because of China's point of view on international relations, since Chinese rulers did not consider western countries as an equal power to China regarding military, political and economic power, and all the time looked down on others. Moreover, from the Chinese emperors's perspective, China was not in need of establishing trade relations, either with any western nations or any other nations in the globe, inasmuch as China was a self-sufficient and rich country concerning economic and natural resources.

Though Canton remained open to the western traders and merchants, they did not make a contact with Chinese traders as well as Chinese officials directly. By 1702, an individual system, so-called 'the emperor's Merchant', was established and assigned as the solely representative with whom the foreign traders and merchants could do business. However, the system proved its unsatisfactory and was replaced fifty years later with 'security merchants', also known as the Co- 
hong, whic is the guild of Chinese merchants being involved in foreign trade. The Co-hong system was abolished in 1771, but it was revitalized in 1782 again, and remained in force until 1842 when the Treaty of Nanking was signed by China and Great Britain as a result of first Opium War (183942) between them (Harold, 1950).

This article, beyond the introduction and conclusion, is organized into seven sections. In the first section, as a theoretical framework, I use balancing strategy so as to explain Chinese response to the West. In the second section, I examine the early expansion of Qing empire towards West and South, and as a consequence of expension, early contacts between Manchus and west, especially, Russia in the west and Britain in the south. In the third section, I give a comparison amid China and West during the 19th century as well as new developments happened in the west in the wake of industrial revolution and influence of the 19th century on China. Section four discusses the process going to first Opium War, reasons and consequences of war, and new treaties concluded between China and westerners. Section five handles the second Opium War and the questions of how China's sense of superiorirt ended up and of how China had to be opened to foreign trade by force entirely. In the last two sections, I evaluate Chinese response to West as both an external balancing act, and internal balancing act respectively, and I also shed light on the reason why China failed to respond to the West.

\section{Balancing}

The idea that states join in alliances to escape domination by stronger nations constitutes the basic logic of traditional balance of power theory. This assumption indicates that nations participate in alliances to protect themselves from another nation or group of nations whose superior resources could pose an important menace to its existence and survival. Therefore, nations choose balancing for two reasons. Firstly, countries might put at risk their existence and survival if they do not realize to thwart a potential hegemon from dominating before it becomes so powerful. Forming an alliance with dominant power means putting "one's trust in its continued benevolence" (Edward, 1967). Thus, the more conveinent policy is to form an alliance with those who cannot dominate others, in order to avoid being dominated by those who can. Secondly, a coalition with weaker side increases the new member's influence inasmuch as the more vulnerable party need greater economic and military aid and assistance. However, coalition with stronger side narrows the new member's influence, in that it gives the alliance, relatively, limited contribution, and leaves it weak and vulnerable to the preferences of its new ally. Therefore, participating in the weaker side is more conveinent and preferred option (Waltz, 1979).

The balance of power theory says that a policy of a state or group of states attempt to conserve itself against another state or group of states by increacing its own power against that of others. A country that encountered a national security equation can follow a balance of power theory in two distinct ways. One is to enhance its own power by building army while the other one is to form an alliance with another state or group of states (Ari, 2013). In other word, states can choose either internal balancing or external balancing in order to cope with the national security equation. If a nation prefers internal balancing as a strategy, it has to build the military capabilities via its own efforts. In a sense, internal balancing is a self-reliance strategy because the country does not rely on other countries for its security (Fatton, 2018).

Different from internal balancing, external balancing aims to coalesce with other states and to increase the power of allies to cope with a common threat (Waltz, 1979). External balancing 
provides a country with some benefits compared to internal balancing. Namely, it reduces the domestic losses and costs associated with internal balancing because it divides the burden of an allience among members for a credible deterrence. However, it also possesses some risks within it since in case of a crisis, conflict or war, any ally cannot give support to its ally by withdrawing allaince commitments (Synder, 1997; Fatton, 2018). Throughout the 19th century, in particular, in the wake of defeats in Opium Wars, as seen below, China tried to benefit from both internal balancing - which is self-strengthening movement, especially, in the military arena - and external balancing strategies - not by means of military alliance, but most favoured nation clause as a different instrument - against westerners.

\section{Manchu Period (1644-1911) and Relations With West}

At the outset of the 17th century, a new dynasty called Qing dynasty showed up and conqured China. Substantially, the Qing state consisted of many distinct ethnic origins, in particular, dwelling in the Northeast part of the country. The descendant of Jurchen tribes who had played a crucial role during the twelfth century, Manchus played a leading role in new state. Other significant tribes such as Mongols, Chinese and Koreans also constituted the ethnic components of new Qinq state. They considered the old Ming dynasty as a corrupt and degenerate and claimed that they was chosen to get the Mandate of Heaven and rejuvenate China (Roberts and Westad, 2013). They adopted a new ideology including conquest and domination as well as old Confucian principles and practices.

By the early 18th centurty, in the western Mongolia, a khan, Tsewang stired up a revolt aganist Chinese by benefitting from local unrests in the region. The uprising paved the way for China to conquer the whole of Mongolia and East Turkestan. Then, Tsewang tried to expand his power and influence towards Tibet, but this also triggered Chinese to invade Lhasa, capital of Tibet, by launching a military operation against Tibet. Therefore, Tibet became a sort of protectorate under the mandate of heaven and Qing state appointed a new Dalai Lama to the region as a supreme ruler. Hereby, new Qing state brought Tibet and Mongolian under control in its early years. Moreover, Korea and Vietnam admitted the Chinese superiority as a tribute states whereas Taiwan was taken over. Besides, some kingdoms in the south like Ryukyu and Burma acknowledged the domination of Qing state and they started to pay tribute to Chinese. Manchus also pursued an expansionist policy aimed at Central Asia, and they brought almost whole of AsiaPacific region under their rule and control during the early years of 18th century (Armaoglu, 2016).

The expansionist ambitions of Qing dynasty resulted in contacting with Tsarist Russia having an expansionist aimes across Central Asia. It was a new issue for China. Manchus destroyed a castle in 1685, which was consturcted by Russians along the Amur river in 1650 because Manchus regarded this region as part of their lands. In other respects, Qing state wanted a neutral Russia so as to materialize its other ambitions in the west. Therefore, Manchu Qing empire and Tsarist Russian empire oranized a series of bilateral talks in order to carve Central Asia up amid themselves. As a result of talks, both sides concluded, as mentioned above, the Treaty of Nerchinsk in 1689 (Urbansky, 2020; Armaoglu, 2016). In the wake of the treaty China became a significant power in Central Asia.

However, within a half of century, in 1727, Tsarist Russia demanded new talks and a revision of the Treaty of Nerchinsk owing to translation problems in Chinese, Russian and Manchurian. Chinese emperor found this request as right and both sides signed a new agreement. New 
agreement gave Russia some rights such as opening a mission, commercial agency and maintainance of a church in Beijing. These rights marked the begining of foreign capitulations (Eberhard, 1947). However, Chinese evaluated that there was no special concessions in the agreement while westerners assessed the agreement quite differently than Manchus in terms of opening a mission and permission to trade. According to Europeans, these steps should have marked the beginning of diplomatic relations between China and west. Yet, both sides misinterpreted each other and this misunderstanding would cause crucial political strifes throughout 19th century.

At the epoch of Ch'ien-lun (1736-1796), the war in Turkestan launched again. As a consequence of a defeat given by the Chinese, Kalmuks immigrated to Ili region where they possessed supremacy over Turkish peoples. Though all efforts made by Kalmuks against China during their fights, they had to renounce half of their soils to Manchus with an agreement concluded in 1739. In the following period, the Qinq empire concerned about probability that some Kazaks origins might reunite against Manchu rule so as to invade and seize the Ili region. Certain unrests occured among Mohammedans during 1750's, and the Qing dynasty seized some important cities such as Kashgar, Yarkand and Uch. These military conflicts caused Manchus to enter a new military clashes with the European colonial powers. At one time, Hi region, a buffer zone amid Russia and China went to Russia step by step between 1847-81. Throughout those years, Kalmuks and Kazaks played a significant role in Sino-Russian relations. Manchus wished Kalmuks to be dispatched to far west through Volga river. However, since Russian enhanced its leverage on Kalmuks, they determined to return to China (1771) (Eberhard, 1947).

Russia was, of course, not the only European country that China came into contact during these years. In the south, Great Britain occupied and captured Calcutta and Bengal in 1757 and 1766 respectively. Manchus achived to subject Burma to China once again in 1769, and in next two years, they completed the conquest and subjugation of Nepal and southern Tibet. These developments brought Chinese and British political and economic interest to conflict in this region. The industry and navigation in Britain improved quickly during 18th century, and as a consequence of this rapid improvement, Britain engaged in trade relation with many parts of world. China was the country in which Bratin showed most interest. Almost half of trade ships arrving Canton port belonged to Britain.

Britain conducted its trade relations with China via Canton port which was only open port for foreigners in China during the 18th century. Yet, as a monopol, the East India Compnay (EIC) dominated this trade relationship. The company engaged in trade with china since the early years of the century, and it was in so dominant position that Chinese authorities had admitted the company's representative role for not only British nationals but also all foreigners. Therefore, all foreign traders wanting to trade with China had to ask for permission from compnay's officials. However, despite this sort of permission, at the beginning of 18th century Britain established the biggest colony in China (Harold, 1950).

British merchants, disappointed with certain limitations, wrote a petition to the British King, George III to demand to open China for foreign trade without restrictions. Thereupon, Britain sent its first trade committee to China under Lord George McCartney together with more than 700 people including diplomats, businesspeople, military officials and scientists, with many gifts in order to be delivered to Chinese emperor in 1792 (Keay, 2011). However, before the committe 
came to China, the Chinese emperor, Zhangzong announced "the celestial empire possesses all things in great abundance and lacks no products within its borders, there is, therefore, no need to import the manufuctures of outside barbarians in exchange for our own products" (Jacques, 2009). The main aim of the British committee was to entice the Chinese emperor to open Qing empire for foreign trade freely. The committee arriving to, firstly, Macau could not accomplish a result of negotiations made with respresentatives of Chinese emperor, and, hereupon, they went to Beijing so as to confer with emperor Qianlong.

McCartney offered British's suggestions to Chinese emperor, such as to open a permenant embassy in China, to terminate the system allowing foreigners to use only Canton port as a trade port, to open new ports for foreign trade in China and equitable and righteous custom tarrifs. Yet, emperor Qianlong did not view the Bristish suggestions positively. Rather, it can be thought that McCartney's efforts were very remerkable at this time when China was still powerful, large, selfconfident and self-assertive and be able to dictate the terms and conditions for any agreement. Thereby, emperor Qianlong wrote a letter in response to British King George III, stating "thank you for sending these gifts, thank you for maintaining control over your territory. It is not necesseray for you to send future gifts for we have all that we need, all that we require in great abundance" (Jacques, 2009).

Therefore, McCartney and his committee returned empty-handed from China, but to him, any Chinese resistence against British demands was futile. One important event happened before sides lanched to negotiate was that McCartney resisted Chinese suggestion that he should kowtow in front of Chinese emperor unless Chinese rulers do the same in front of British king George's portraiture. He propsed kissing the hand of and kneeling in front of Chinese emperor. However, the suggestion could not be admitted by Chinese because, in Chinese political thought, the emperor was the only master of everything under heaven, and any king or emperor in the world is not equal to the Chinese emperor. Furthermore, goods that British committee brought as gifts were considered by Chinese as another problem since, in Chinese tradition, foreigners were the second class people who visit China and bring tribute. Accordingly, Chinese opined that McCartney was not a privileged and special person, but an ordinary foreigner having to offer tribute to China whereas McCartney viewed that goods were presents of someone being equal to emperor in terms of diplomatic practices. Consequently, sides failed to reach a rapproachment (Keay, 2011).

During the late 18th and early 19th century, even though European countries gave weight to relations with China, China did not pay attention to relations with westerners in the same vein since Chinese authorities evaluated that westerners were in need of Chinese goods and products and needed to trade with China. Yet, China was not in need to do so. Therefore, China followed a policy looking down on westerners. In spite of Chinese views, Britain adopted a new policy, which is that Britain would gain trade monopoly from the East Indian Company that had kept for a long time inasmuch as she wished to establish official relations with China directly without a broker. Britain was dissatisfied with trade that EIC made because it did not meet the needs of British government, and it allowed Britain to trade in a limited area. Whereas, British government assessed that China was an enourmous market for Britain, especially, with regard to British textile industry. For that reason, building offical relations with Qing China gained importance for Britain considerably. Yet, all efforts of Britain to open a diplomatic mission in China yielded no result 
throughout those years. The Chinese thought and attitude towards Britain necessitated Britain to find alternative ways. Those alternatives will be mentioned in the next chapters (Jacques, 2009).

The Rise of New Powers After Industrial Revolution and Influence of the 19th Century on China

The new century was, in the full sense of the word, a European centurty since European nations started to dominate world politics as well as world economics. Instead, European domination began earlier than 19th century on world, yet it was not in every area. Altough European nations initiated their colonial activities and created their colonies around world, globe was not a uniform entity which westerners ruled over directly or indirectly yet. The new century contributed westerners to create this supremacy via imperialism led by industrialization, which, for the first time, took place in Great Britain, and called "Industrial Revolution". Improvements that occured in industrial field led to industrialization owing to technical advances happened in 1801-1870 (Akyilmaz, 2015).

Therefore, world changed tremendously throughout the 19th century due to industrial improvements, scientific revolutions and emergence of new powers. Many improvements and inventions like railroad, steamship, telegraph, modern transportation and communication technologies and so on tied the globe to each other considerably, to some extent it had never been seen before in history. The utilization of these new inventions on production methods resulted in the economic welfare of western powers to enhance substantially. Economic richess promoted western powers to set up their supremacy and domination on other countries through new weapons and developments in the armament industry (Bairoch, 1982). The use of these inventions as well as steam machines had a profound impact on the production and manufacturing of developed mechanization in terms of industrial field. Thus, western nations found an opportunity to increase their capital accumulation significantly. Furthermore, the power and affluence of industrialized countries presented them as model nations in the minds of other countries around world. Hence, apart from industrialized powers, many communities did not comprehend what modernizm symbolizes, and even some of them rejected and resisted against it for a long time (Akyilmaz, 2015).

As to China, at the outset of the century, it was such a enourmous empire that its lands far exceeded, even, today's People's Republic of China's territories with largest population and largest land in the world, including Mongolia and Turkestan in a total of more than 9 million square metres and with more than 400 million population (Chesnaux, Bastid and Bergére 1977). It had a good quality living standarts analogue to western Europe during the 18th century. Even, in light of some estimations, it can be said that Europe was behind of China in some areas like labour, land and production markets and so on, and any comparision to China is out of question (Bairoch, 1982). Considereing the economical statistics, throughout Qing dynasty, China's economy was largest and richest economy in the world from 1700 to 1820 's, when it ranked the first in the world with growing proportion between $22.3 \%$ and $32.9 \%$ (Qu, 2016; Sun, 2011). Nonetheless, new developments occured during the 19th century brought about China's share in world production to shrink to merely $6 \%$ at the end of century. The most significant reason of this decline was that newly industrialized nations expanded their economies disproportionately while China was getting impoverished during this century. Moreover, the Qing China faced new empires surrounding it, 
and countries, once upon a time, that paid tribute to China fell into the hands of colonial powers, and became colonized by them.

\section{Anglo-China Relations and Opium War}

As abovementioned, trade that foreigners engaged in China was restricted by Manchus to merely Canton port since 1760, but Russians and Chinese merchants were exempted from this restriction. All western traders and mechants faced these restrictions (Perdue, 2005). Britains played the most significant role among western merchants. They loved tea so much that it became main import item for them from China, reaching a peak of 15,000 tons in 1830's though it was very narrowed at the outset (Keay, 2011). For foreign merchansts, one firm played a very crucial role in trade; that is East Indian Company. It, for the first time, came to China in 1691 after it took hold in India following the fire of Spice islands in Indonesia by the Dutch. It was trading cotton products produced in India between India and Britain. It launced sailing to Canton port regularly since the early of 18th century, and within a short period of time, EIC created a trade monopoly with China for all foreign merchants including British nationals as well. Nonetheless, British citizens took advantage of some special priviligies compared to other nationals (Perdue, 2005).

At the beginning of the 18th century when China gave to the EIC additional businesses, the company started to gain huge affluence. Tea that Britains loved and needed so much became the most important income source for EIC. The total value of tea Britain sold in England in 1790 amounted to approximately 9 million sterling, and demand for tea continued to grow in the coming century. By 1834, tea accounted for more or less $10 \%$ of all income of British government. Altough both British and other western countries sold many goods in exchange for Chinese silk, porcelain, tea and so on, nonethless, they had a foreign trade deficit against China. There was a strong trade inequality between West and China, and silver was flowing to China from West. Therefore, Britain began to seek for a new products instead of silver so as to pay for imported goods and products from China, and so they discovered opium at the end of the 18th century. Tea and opium was totaly different products from each other, but in British's eyes, there is no difference amid them regarding economic value (Keay, 2011). China's demand for British goods was too low inasmuch as Chinese did not feel the need of British products. Therefore, Qing China took benefited from trade surplus in its trade with Britain throughout the 18th century.

At the outset, opium was so little in China that merely 200 cases opium were imported in 1729 when Chinese emperor forbade the opium. Moreover, local production was so limited. A starvation happaned in Bengal in 1770 caused EIC to ask help from English parliament. Thereby, a tea agreement was concluded and EIC could sell its goods to British colonies with free of tax. EIC created a monopoly in opium production in Bengal in 1770's, and thus it could export to China more than 60 tons of opium per year. The opium trade grew considerably year by year, and company did not care about ban that Canton authorities had repeatedly mentioned (Keay, 2011). By 1828, the number of opium cases arrived in China reached 13,000, and it reduplicated itself within next eight years. The financial value of this trade was nearly 18 million dollars in those years. Therefore, opium became the most crucial and precious trade for Britan in the 19th century. According to Britain, tea trade should not have made with silver anyomore since opium was enough to balance this trade. Thus, the flow of silver to China halted and balance of trade between China and Britain went in Britain's favour (Harold, 1950). 
Chinese had utilized opium for medical purposes for a long time, hence an unprecedented opium usage and dependence for pleasure emerged as an important problem throughout the 17th century. The main concern was that unless the use of opium was prevented, the treasure of Qing state would be faced a disastrous consequences within a short time, and even the country would be vulnerable to foreign assaults, and the country might have conquered without resorting to military campaign. The Chinese emperor and those witnessing the adverse effects of the opium on public described it as evil. The incapability of Manchus to halt opium trade and use as well as the greed of the British East India Company and Chinese smugglers worsened the situation significantly (Kalipci, 2018). Therefore, the Chinese emperor, Qianlong appointed Lin Tse-hsu as an imperial commissioner so as to inspect ships which transported products and goods to the country. He went to Canton to deal with the question by taking trade under control in an orderly fashion in 1839. As soon as he arrived to Canton, he embarked on an investigation, which he found that all local authorities and administratiors were either taking bribe or obtaining a share of opium trade. He, immediately, dismissed those officials from positions, and then he warned British to terminate the opium trade at once and to deliver all opium they had (Rowntree, 1995).

The British Chief, and trade chief of westerners, Carles Eliot in Canton did not have enough power to resist Chinese. In fact, his authority was limited to private businesspeople. He also did not have sufficient time to wait for instructions coming from London because it could not come before at least six mounths. For that reason, Eliot told to foreigners to hand all opium over to Chinese officers in exchange for promise he gave that British government would meet all loses they faced. Thus, foreigners delivered to Lin more than 20.000 cases of opium, and all opium was annihilated by Lin and his officers. Furthermore, Lin asked foreigners to sign a commitment stipulating that they would not bring and sell opium in China anymore. However, certain British merchants refused this commitments since it would mean that British nationals would be on trial in Chinese courts according to Chinese laws (Holcombe, 2016).

Therefore, a few serious question like opium debates, protocol and diplomatic representation, commercial income and trade rights led to enmity between sides. British Prime Minister, Lord Palmerston disapproved the demand for sending an army made by C. Eliot, but the opium barons made his decision to change for this demand, and so an army consiting of a large land and navy left Indian so as to go to China. Within a short time, Brtish navy blockaded Chinese ports, it did not permit them to navigate, and it seized some Chinese territories. On March 1840 when British forces came to Chinese shores and went towards Yangtze river, a war erupted amid two empires (Keay, 2011). While, in its course towards north, British forces captured some significant Chinese harbours and cities like Tinghai, Ningpo, Amoy, Chinhai, Nanking and Chinkiang. On june 1842, British forces invaded Shanghai and Nanking, old emperial capital fell into the hands of British invaders. When British forces cut the communiciation line and halted the contact amid Yangtze river and Nanking, both sides embarked on peace talks, and thus, the Treaty of Nanking signed on 29 August 1842 (Harold, 1950). The treaty stipulates that; A British officer would reside in Canton and could talk with Chinese authorities if necessary; In addition to Canton, ports in amoy, Shanghai, Foochow and Nigpo would be opened to foreign trade; Customs duty and tarrifs would not be exceed $5 \%$; Brtish national would not be allowed to be on trial in Chinese courts according to Chinese laws; Britain would take advantage of the most favored nation clause; Britain could create a colony in Hong Kong; Qing empire would admit to pay 21 million dollars as war indemnity to Britain; Co-Hong system would be terminated (Armaoglu, 2016). 
The emperor Qianlong announced on 26 June 1843 that he acknowledged all those conditions. However, it is remarkable that any terms stipulating the ban of opium smuggling did not exist in the treaty. Therefore, smuggling continued for a long time under the auspices of British navy. The treaty marked a new period for China since it was increasingly getting a semi-colony in favor of westerners because following the treaty, other westerners also entered to China through similar kind of treaties. For instance, the Treaty of Whampoa amid China and Frane and the Treaty of Wanghia amid China and the United States were concluded in 1844. With all those treaties, western powers could enter to and engage in their activities in China (Armaoglu, 2016; Eberhard, 1947). Britain began to build a military base in Hong Kong via the treaty of Nanking. Moreover, this treaty paved the way for a capitulation period to launch in China. Chinese saw it as one of the most negative sides of the treaty terms. One more negative sides is also that it stipulated the most favored nation clause, which Britain would capitalize on whenever Qing empire concludes a new agreement with or bestow upon new concessions to another country.

\section{Second Opium War (1856-1860) and Treaty Revision}

The Treaty of Nanking did not satisfy either Britain or China, for some malfunctions and inadequacies happened while bening exerted. Furthermore, China was struggling with Taiping revolution (1850-64), and France and Britain saw the situation as a chance in order to revise the treaties, and so they resorted to Chinese authorities to be able to do changes in the treaties. The most important request was that diplomatic representatives of both countries would, in perpetuatiy, reside in Peking according to the principle of equality of states. Yet, Chinese resisted these permenant missions and applied for distraction tactics (Harold, 1950). At this time, four western countries including Britain, France, Russia and the United States were attempting to set up more satisfactory relations with and to gain more trade privileges from China. However, second Opium War was initiated by Britain who had long been looking for ways to gain more trade priviliges, utilizing the Arrov incident as a pretext, which the event was that a Chinese ship recorded by Britain was halted by Chinese officials, and they arrested a few crews in the ship in 1856. Britain also claimed that Chinese exhibited a disrespectful attitude for the British flag. Therefore, British used this as an excuse for war against China, and a war erupted in 1856 between sides. France wishing to get involved in the war participated in British forces, on the excuse of Chinese killed a French catholic missionary. As a consequence of war, Britain and France dictated the Treaty of Tianjin to China to sign in 1858, yet, Chinese officials rejected to approve it, and thus war restarted once again (Zhang, 1998).

Other two actors, Russia and the United states also joined in this campaign, but they did not conduct any hostile activity towards China. The US kept on carring out a policy of peaceful talks in China. Moreover, Russia started to be involved in a peaceful negotiations. Yet, because of its advance along the Pacific, tsarist Russia was able to put a pressure on China. It demanded a change over regional status of the northern frontier amid China and Russia through a new agreement from China. China who considered Russia as a balancing actor in its struggle with France and Britain recognized a new treaty with Russia, and thus the treaty of Augin that recognize Russian existence in northern side of Argun and Amur rivers (Harold, 1950).

For that reason, France and Britain advanced towards Tientsin region in the north. American and Russian negotiators pursued this campaign, and western powers went into division. British and France joint forces launched a bombardment campaign in Canton, and then embarked 
on advancing towards the capital, Peking by capturing many places. This advance paved the way for the Treaty of Tien-tsin that China had to sign with Britain and France in June 1858 on the following terms; China would open eleven new ports to foreign trade; A permenant British embassy would exist in Peking; Along the Yangtze river, China would guarantee the freedom of navigation; China would permit British nationals to purchase land in China; British nationals could be on trial in British courts according to British laws; Chinese would allow westerners to engane in missionary activities in China; trade treaty would be revized and opium trade would be allowed; A war indemnity would be exposed on China and France would do trade in Formosa island (Eberhard, 1947).

Upon arriving at China, new British ambassador, Frederich Bruce saw that water routes to Peking were blockeded by Chinese. Thereby, he sued for a British naval force so as to terminate the blockade on his way. Hence, Chinese fired British forces and caused a conflict between sides with left 519 deaths. It was the first Chinese victory against west and destroyed the idea of weak China in relation to west. However, a new British and France joint military force launced another military campaign against China on August 1860. They set fire to the summer palace of the Qing emperor while more than 200.000 troops were going to Peking from Tien-tsin. In the meantime, Chinese emperor fled to Jehol where he died. Eventually, China had to come the treaty of Tientsin into force through Peking agreements (Kissenger, 2011).

Superficially, the treaty of Tien-tsin opened whole China to foreign trade, but in practice, the situation was a bit distinct because Taiping revolutinaries established a government in Nanjing and also declared the city as their capital. One important question related to Taipings was that they were against foreign trade. Through the help of Peking government, British and France forces took action against Taipings, which they seized Nanjing and put an end Nanjing government and Taiping revolutionaries between 1862 and 1864. Hereby, the last impediment to open whole China to foreign trade was removed (Eberhard, 1947).

While all these developments were taking place, Russia showed up with a mediation suggestion in dispute of 1860. This was a sort of foreign intervention and threat for use of force in one sense. The fully entitled agent of Russian tsar in China, Nikolay Ignatief enticed Chinese emperor that merely Russia might run western powers out of China, and merely Russians might force western nations to obey with the conditions proposed by Chinese (Harold, 1950). For certain, Russians made significant territorial demands in return to their help. Thus, they asked China to cede a huge land so-called Vladivostok located in northestern China. Russia constructed a naval base immediately there and gained an important foothold in the far east and in the sea of Japan. Chinese had admitted Russian proposals because of one reason, which was to use one barbarian against another barbarian. This balancing act, from Chinese point of view, was a conveinent policy whenever treaty powers gained a superiority in Peking. However, the results of this policy were heavy and costly on China.

\section{Using Barbarinas Against Barbarians}

Here, I call the policy of "using barbarinas against barbarians" implemedented by Qing China as an external balancing act, but I, in a classical sense, diffirentiate it from military alliance with any other country. Namely, the main argument is the concept of "most favoured nation clause", but not military alliance. Let me make it clear, China that tried to survive between, throughout the 19th century, superior technologies and dangerous attacks of western Europeans 
and new ambitious of Russia and of Japan, mostly, took advantage of her capable diplomats and cultural ties. By the middle of 19th century, few number of Chinese started to grasp that they no longer lived in a system where Chinese superipority dominated, and that they had to learn the essentials and principles of a system of competing power blocks. One of such officials was Wei Yuan (1794-1856) who was a midranking Confucian mandarin. He suggested that China had to implemet lessons that had to be taken from the system of European balance of power, for China's contemporary problems. Therefore, he offered some methods whereby China might gain a margin for maneuver (Kissenger, 2011). His strategy proposes that:

"There are two methods of attacking the barbarians, namely, to stimulate countries unfriendly to the barbarians to make an attack on them, and to learn the superior skills of the barbarians in order to control them. There are two methods of making peace with the barbarians, namely, to let the various trading nations conduct their trade so as to maintain peace with the barbarians, and to support the first treaty of the Opium War so as to maintain international trade" (Teng and Fairbank, 1979; Kissenger, 2011).

On the other hand, Wei Yuan eximanied the nations that, depended on the principles of European balance of power, could probably put pressure on Great Britain. He analysed the world, examining the hostile nations that British barbarians feared. He indicated "Russia, France, and America" in the West, and "the Gurkhas of (Nepal), Burma, Siam (Thailand), and Annam (northern Vietnam)" in the East as potential candidates. He imagined a two-pronged Russian and Gurkha assault on Britain's Indian empire since according to him Britain's Indian empire was the most distant from center and poorly defended. Provoking long-termed French and American hostilities aimed at Britain, leading them to make an assault Britain via sea, was another weapon in Wei Yuan's mindset (Kissenger, 2011).

This idea was very strange to implemet at that time because China had very limited knowledge about, and had no permanent embassies in those potential candidate countries to form an alliance. Thus, another interesting idea came up, which was put forth by Wei Yuan once again. According to this new plan: summon other barbarians into China and create a comptetiton amid them and Britain in order that China could become as a balancer in a contest over the share of its own substance (Kissenger, 2011). Wei Yuan proposed that:

"Today the British barbarians not only have occupied Hong-kong and accumulated a great deal of wealth as well as a proud face among the other barbarians, but also have opened the ports and cut down the various charges so as to grant favor to other barbarians. Rather than let the British barbarians be good to them in order to enlarge their following, would it not be better for us ourselves to be good to them, in order to get them under control like fingers on the arm?" (Teng and Fairbank, 1979; Kissenger, 2011).

Put it differently, China ought to give privileges to all greedy countries rather than allow Britain force them and enjoy itself by proposing to share the lands with other nations. The instrument for accomplishing this aim was the Most Favoured Nation principle. According to this principle, any concession given one country ough to be automatically expanded to all countriess (Hsu, 2000).

\section{Self-Strengthening Movement (1864-1884)}


Following the defeats in Opium wars, Chinese started to view that their sense of superiority over other peoples for centuries be abraded. Their world order including the tribute system, the mandate of heaven and the isolationist trade policies seemed outmoded and inexpedient. As western power initiated to resort to force and become influential on Qing empire, many people consisting scholars and officials in China would consider a need to imitate the technology, organizational hierarchy and cultural traditions western nations benefitted from because they thought that through these imitations, they might have prevent China from being subjugating by western imperialism. This was a beginning of a reform process and emulation called "SelfStrenghening Movement". With regards to scope, this reform movement aimed at western-style modernization in many fields covering military and industrial technology, intellectual and academic thoughts, reorganization of the military organizational and diplomatic system, economic restructuring and so on $(\mathrm{Qu}, 2016)$.

Hence, self-strengthening movement significantly limited itself to material matters, like the development of weapon and transportation infrastructure. Chinese opined that modern military materials and equipments like steamships, guns and cannons would provide China with the physical force it needed to push out and not to let foreign troops to penetrate into China ( $\mathrm{Qu}, 2016)$. For that reason, in the military arena, changes in weapons and training methods came to be assumed as fundamental to the self-strengthening attempt. The main reason why Qing dynasty saw the changes in weapons and traning methods significant were, of course, bad experiences in devastating Taiping Rebellion and humiliated defeats in two Opium Wars against western powers. These events necessitated Qing dynasty to introduce western-style weapons, guns and equipments and training methods to Chinese military structure (Smith, 1976).

However, at that time, in order to be able to modernize its army, China needed a capital, which it had not enough sum to meet the requirements for the modernization. Therefore, China, for the first time in its history, borrowed foreign loans to achive its modernization project. The most important aim of the foreign loans was to modernize the Chinese military, especially, the navy. Prince Gong set up "Zongli Yamen" in order to conduct relations with western nations through diplomacy and to promote self-strengthening movement. It had a vital role with respect to embracement of western technology in Chinese army and industry. Prince Gong and Li Hong Zhang took up responsibility for this purposes, and they benefitted from foreign advisors and technologies as well as loans. Thereby, local governers in certain coastal cities, such as Shanghai, Nanking, Nigbo, Tianjin and Foochow initiated to construct military arsenals through the support and help offered by Prince Gong, Li Hong Zhang and foreign advisors. As a result of reform movement, the Qing empire had the seventh largest navy on globe, but it should not be forget that despite the size of navy and many improvements in Chinese army, the project for modernization was very costly and inadequate inasmuch as weapons and other equipments produced in China were insufficent in terms of quality in comparision to that of Europeans. That's why the Chinese government had to purchase foreign weapons, resources, equipments and components from European nations for production in China (Hwan, 2009; Feis, 1930).

Despite some achievements, the reform movement called self-strengthening ended up failing. There are a few reasons behind this failure. To begin with, Chinese authorities had diffirence of opinion as to the movement, which they divided into two camps. One camp was conservative party, who consistently opposed and sabotaged the progress made and achieved by 
reformers. There was no room to reach a conciliation between conservatives and reformers. As a consequence, few important accomplishments were materialized because of the fact that ruling elites thought the situation differently. One argument that conservatives brought forward was that embracing western technology were offscourings for China's greatness and dignity. This, perhaps, can be explained by China's xenophobic senses against the west. On the other hand, when it comes to reformers or progressives, when they put forth their suggestions and plans, their power was very limited and had not assurance to materialize them. The reformers centers were principally distributed amid provincial and regional governments. Therefore, they were not able to make the reform movement successful on a national scale. That was because some authorities in the central government were prone to be more receptive to conservatives's ideas (Kucha and Llewellyn, 2019).

Another reason why the reform movement failed was that some Chinese ruling elites were reluctant to change and modernize their political system. Reformers admitted that the selfstrengthening movement aimed at defense of the nation, yet the ways to achieve this purpose were to possess the technology. It looks like that they did not take social and cultural factors, in particular, modernist ideology, into consideration much seriously. For them, main aim was to conserve, not to change. As a third reason, it can be said that some new industries and firms could scarcely avoid from method of government-supervised, and merchant-managed eventally caused degeneration, corruption and malpractice (Huang, 2021). Consequently, as an internal balancing act, the self-strengthening movement had a very limited success story, only in military areas.

\section{Conclusion}

Despite the definite defeat in the first Opium War, Chinese evaluated that China was still great and superior to westerners. However, this opinion would change dramatically as a consequence of the second Opium War. Westerners fired and looted the Summer Palace of the Qing emperor who escaped to Jehol from Peking, in which he passed away. In the wake of second Opium War, Chinese concluded the Treaty of Tianjin and Peking Convention with Europen powers, which eliminated gradually the sense of superiority for Chinese. Therefore, via these treaties, westerners obtained the right to establish a military base and diplomatic immunity and right for their nationals to move freely in China.

During the 19th century when China encoutered superior western technology and western imperialist powers, in particular, as a result of Opium Wars, she had limited options to follow and cope with westerners. Chinese chose two strategies, which one is a kind of external balancing, but not in a military sense classcally, but as an instrument via the concept of most nation favoured clause. Namely, by inviting other powers to China, Chinese aimed to create a rivalry among westerners and to benefit from this contest. Yet, the result did not happen as Chinese hoped for. The other option or strategy Chinese implemented is a sort of internal balancing through selfstrenghening movement, especially, in the military arena by building arms and armament, however, neither those policies prevented China from becoming a semi-colonized country during the second half of 19th century in power game, and as a consequence, since China did not keep up with new conditions in international system in the 19th century, it started to lose more than anyone else. 


\section{REFERENCES}

Akyilmaz, G. (2015). Siyasi Tarih. Ankara: Seckin Yayınları.

Armaoglu, F. (2016). 19. Yuzyil Siyasi Tarihi 1789-1914. Istanbul: Timaş Yayınları.

Ari, T. (2013). Uluslararasi Iliskiler Teorileri: Catisma, Hegemonya, Isbirligi. Bursa. MKM.

Bairoch, P. (1982). International Industrialization Levels From 1750 to 1980. Journal of European Conomic History, 11, No. 2.

Eberhard, W. (1947). Cin Tarihi. Ankara: Turk Tarih Kurumu.

Edward, G., V. (1967). Europe's Classical Balance of Power. New York: W. W. Norton and Company, Inc.

Fatton, L. P. (2018)'Japan is back': Autonomy and balancing amidst an unstable China-U.S.Japan triangle'. Asia \& The Pacific Policy Studies. DOI: 10.1002/app5.240. 5:264-278.

Feis, H. (1930). The World's Banker: 1870-1914 New Haven: Yale Press.

Holcombe, C. (2016). A History of East Asia: From the Origins of Civilization to the Twenty-First century. Cambridge: Cambridge University Press.

Harold, V, M. (1945). A History of The Far East In Modern Times. New York: F. S. Crofts \& CO.

Huang, G. (2021). China's Self-Strengthening Movement and Japan's Meiji Restoration. Available at https://www.ia-forum.org/Files/YIUBIF.pdf, (accessed on 20 May, 2021).

Hsu, I, C. Y. (2000). The Rise of Modern China. Oxford: Oxford University Press.

Hwan, S. (2009). Chinese Loans 1861-1911. Korean Minjok Leadership Academy, Internationa Program, Research Paper.

Chesnaux, J., Bastid, M., and Bergére, M,. (1977). China from the Opium Wars to the 1911 Revolution, İngilizce'ye çeviren: Anne Destenay, Sussex: The Harvester Press Ltd.

Kalipci, M. (2018). Economic Effects of the Opium Wars for Imperial China: The Downfall of An Empire, AIBU Sosyal Bilimler Enstitusu Dergisi, Vol:18, Year:18, No. 3, 18 pp.291-304.

Keay, J. (2011). Cin Tarihi. Cev. Dinc Tayanc. Istanbul: Inkilap Kitabevi.

Kissenger, H. (2011). On China. London: The Penguin Press.

Kucha, G. and Llewellyn, J. (2019). The Self-Strengthening Movement, Alpha History, Available at https://alphahistory.com/chineserevolution/self-strengthening-movement/, (accessed on 20 May, 2021).

Jacques, M. (2009). When China Rules The World. London: Penguin Books.

Maddison, A. (2001). The World Economy: A Millenial Perspective. Paris: OECD.

Perdue, P. C., and Marches, C. (2005). West: The Qing Conquests of Central Asia. Cambridge: Cambridge University Press.

Roberts, J. M., and Westad, O. A. (2013). The History of The World. New York: Oxford University Press. 
$10 \begin{aligned} & \text { The } \\ & \text { Journal of } \\ & \text { Social } \\ & \text { Science }\end{aligned}$
Year:5, Volume:5, Number:10/2021

Rowntree, J. (1905). The Imperial Drug Trade. London: Methuen and Co.

Smith, R, J. (1976). Foreign-Training and China's Self-Strengthening: The Case of Feng-HuangShan, 1864-1873, Modern Asian Studies, Wol. 10, No. 2, pp. 195-223.

Snyder, G. H. (1997). Alliance Politics. Ithaca: Cornell University Press.

Teng, S, And Fairbank, J. K. (1979). China's Response to the West: A Documentary Survey, 18391923. Cambridge: Harvard University Press.

Waltz, K. N. (1979). The Theory of International Politics. United States of America. AddisonWesley Publishing Company.

Zhang, W. (1998). Japan versus China in the Industrial Race. NY: St. Martin's Press Inc. 